\title{
CYBERPRZESTRZEŃ JAKO ŚRODOWISKO SPOŁECZEŃSTWA OBYWATELSKIEGO W BRAZYLII
}

\author{
Maria Ochab \\ Wydział Politologii \\ Uniwersytet Marii Curie-Skłodowskiej w Lublinie \\ ORCID ID: https://orcid.org/0000-0002-0061-3558 \\ e-mail: maria.ochab@umcs.edu.pl
}

\begin{abstract}
Streszczenie: Uzyskanie dostępu do nowoczesnych technologii informatycznych i komunikacyjnych stanowiło duże ułatwienie dla działalności organizacji pozarządowych. Dzięki temu nastąpił znaczący rozwój aktywności społeczeństwa obywatelskiego we wszystkich państwach, ale szczególnie istotne znaczenie ma to w przypadku państw, gdzie instytucje rządowe są niewydolne. Taka sytuacja ma miejsce w Brazylii, która została wybrana jako przedmiot analizy w niniejszym tekście. Organizacje pozarządowe, których działalność ma podstawy w dobrowolnej aktywności obywateli skupionych wokół jakiejś sprawy lub idei, muszą ze swej natury opierać się na strukturze sieciowej i wykorzystywać swoje skromne zasoby możliwie najbardziej efektywnie. Przeniesienie dużej części działalności do cyberprzestrzeni pozwoliło na znaczącą poprawę efektywności w następujących obszarach funkcjonowania: komunikacja, informacja, widoczność, współpraca i zarządzanie. Brazylia, choć jest uważana za wschodzące mocarstwo regionalne, nadal boryka się z wieloma problemami społecznymi i ekonomicznymi. Ponadto jej społeczeństwo jest relatywnie młode, co ma znaczenie w kontekście korzystania z nowych technologii komunikacyjnych. W artykule dokonano analizy wybranych brazylijskich organizacji pozarządowych, które prowadzą działalność w cyberprzestrzeni.
\end{abstract}

Słowa kluczowe: społeczeństwo obywatelskie, cyberprzestrzeń, trzeci sektor, Brazylia

\section{WPROWADZENIE}

Celem niniejszego artykułu jest przeanalizowanie, w jaki sposób możliwość korzystania z nowoczesnych technologii dostępnych w cyberprzestrzeni przyczyniła się do rozwoju organizacji reprezentujących społeczeństwo obywatelskie. Gwałtowny postęp w dziedzinie zaawansowanych technologicznie środków przekazu informacji i komunikowania się otworzył całe spektrum nowych możliwości funkcjonowania w życiu społecznym zarówno jednostek, jak i podmiotów zorganizowanych. Łatwość wchodzenia w interakcje z innymi spowodowała 
z kolei eksplozję aktywności o charakterze prospołecznym - w cyberprzestrzeni nazywanej cyberaktywizmem; pojęcie to jeszcze do niedawna nieistniejące. Analiza wspomnianej powyżej kwestii zostanie przeprowadzona na przykładzie Brazylii w celu zweryfikowania przyjętej tezy, iż cyberprzestrzeń jest przyjaznym środowiskiem dla prowadzenia tego typu działań nawet w społeczeństwach, które charakteryzują się bardzo dużymi dysproporcjami rozwojowymi i wysokim poziomem wykluczenia społecznego, dotykającego szerokie rzesze obywateli. Brazylia jest przykładem takiego właśnie społeczeństwa. $Z$ jednej strony jest to państwo o bardzo znaczącym potencjale ekonomicznym i politycznym, uznawane w środowisku międzynarodowym za wschodzące mocarstwo regionalne, a z drugiej wciąż boryka się z wieloma problemami społecznymi, wynikającymi z ubóstwa i wykluczenia społecznego. W obliczu niewydolności brazylijskich instytucji państwowych, ich rolę - oczywiście w ograniczonym zakresie i tylko w pewnych obszarach - zaczynają wypełniać organizacje pozarządowe.

W pierwszej części artykułu autorka skupi się na wskazaniu tego, w jaki sposób tradycyjne życie społeczne przeniesiono do cyberprzestrzeni, jak się tam rozwija i jaki ma to wpływ na stosunki międzyludzkie, a także na różnorodne aspekty funkcjonowania społeczeństwa. Następnie analizie zostanie poddana kwestia tego, w jakich obszarach działalności społeczeństwo obywatelskie może skorzystać na dostępie do nowoczesnych technologii informatycznych i komunikacyjnych. Pod uwagę będą wzięte te aspekty działalności prospołecznej, które w największym stopniu uległy zmianie w wyniku przeniesienia jej do cyberprzestrzeni, czyli: komunikacja, informacja, widoczność, współpraca i zarządzanie. Trzecia i ostatnia część artykułu będzie poświęcona sytuacji sektora pozarządowego w Brazylii wraz z przykładami konkretnych działań podejmowanych przez wybrane brazylijskie organizacje reprezentujące społeczeństwo obywatelskie.

\section{SPOŁECZEŃSTWO W CYBERPRZESTRZENI}

Pojęcie „cyberprzestrzeń”, choć pojawiło się już w latach 80. XX wieku, weszło do użytku powszechnego dopiero wraz z gwałtownym rozwojem internetu. Początkowo sieć była tworzona z zamysłem wykorzystania jej do celów militarnych i naukowych i była dostępna jedynie dla wąskiej grupy specjalistów ${ }^{1}$. Jednak w bardzo szybkim tempie poszerzały się możliwości dostępu do tej nowej technologii, zarówno w zakresie powstawania coraz bardziej zaawansowanych urządzeń (hardware), jak i ich oprogramowania (software). Dzięki temu z jednej

I W latach 50. XX w. z inicjatywy Departamentu Obrony USA naukowcy amerykańscy stworzyli sieć łączącą kilka ośrodków akademickich, które dysponowały komputerami o dużej mocy obliczeniowej w celu wymiany informacji. Tak powstała sieć ARPANET (Advanced Research Projects Agency Network), która była prekursorem Internetu. Zob.: https://www.techopedia.com/ definition/2381/advanced-research-projects-agency-network-arpanet [dostęp: 20.04.2018]. 
strony zaczęło się powiększać grono użytkowników sieci, a z drugiej pojawiało się coraz więcej możliwości jej wykorzystywania do różnych celów. Szybki rozwój technologii i powszechny do niej dostęp wywarły ogromny wpływ na życie współczesnego społeczeństwa. Cyberprzestrzeń zaczęła być traktowana jako nowa kategoria przestrzeni społecznej, w której w odróżnieniu od fizycznej rzeczywistości jest możliwe ominięcie ograniczeń narzucanych przez takie wymiary egzystencji ludzkiej, jak czas i przestrzeń, a jego granice wyznacza jedynie wyobraźnia twórców nowego oprogramowania. To środowisko aktywności ludzkiej dostępne niemalże dla każdego z dowolnego miejsca - choć początkowo miało w zasadzie służyć do komunikacji w celu przesyłania informacji - szybko rozszerzyło swoje pole działania i stało się niezbędnym miejscem dla funkcjonowania wszystkich obywateli i grup społecznych. Zaoferowało im szerokie spektrum nowych możliwości działania i wchodzenia w interakcje z innymi. Aby uświadomić sobie skalę rozwoju sieci internetowej, wystarczy porównać brazylijskie dane statystyczne z lat 2000, kiedy to z internetu korzystało $5 \mathrm{mln}$ osób, czyli 2,9\% obywateli, z danymi za rok 2017, w którym użytkownikami sieci było już ponad $139 \mathrm{mln}$ Brazylijczyków, czyli 65,9\% populacji [Internet World Stats 2017].

Najszybciej i w największym stopniu cyberprzestrzeń zaczęła być wykorzystywana przez sektor prywatny do celów komercyjnych. Internet okazał się doskonałym narzędziem marketingowym, pozwalającym dotrzeć do olbrzymiej liczby konsumentów, w dodatku skutecznie wyselekcjonowanych dzięki profilowaniu ich preferencji zakupowych. Dostęp do cyberprzestrzeni przyczynił się też do gwałtownego rozwoju przemysłu kreatywnego - filmy, muzyka, gry itp. stały się najbardziej popularną, bo dostępną w dowolnym miejscu i czasie (pod warunkiem dostępu do sieci) formą rozrywki. Instytucje państwowe również zaczęły wykorzystywać nowoczesne technologie, choć nie w tak dynamiczny i efektywny sposób, jak sektor prywatny. Niemniej jednak nawet jeśli państwo nie wykorzystuje wszystkich możliwości działania w cyberprzestrzeni w celu np. obniżenia kosztów funkcjonowania aparatu państwowego czy ułatwienia życia obywatelom, na pewno korzysta z możliwości coraz ściślejszej kontroli ich aktywności, choćby w odniesieniu do kontroli przepływów finansowych, działalności gospodarczej, ściągalności podatków, migracji itp. Oczywiście przez władze jest to postrzegane jako korzystne dla funkcjonowania państwa, ale często jest także przedmiotem niepokoju ze strony organizacji broniących praw człowieka, w szczególności prawa do prywatności, ze względu na zagrożenie niekontrolowaną inwigilacją życia obywateli przez państwo. Kwestia ta nie jest jedynym postrzeganym negatywnie aspektem świata wirtualnego. Można w tym miejscu wspomnieć o wpływie nowoczesnych technologii na zmianę relacji międzyludzkich. Wraz z rozwojem nowych technologii cyberprzestrzeń przestała być traktowana jedynie jako jeden z możliwych kanałów do nawiązania kontaktu czy przesłania informacji, a stała się elementem przestrzeni społecznej, do jakiej przeniosła się duża część życia współczesnego społeczeństwa, szczególnie ludzi młodych, nieznających świata sprzed ery cyfrowej. Dla wielu z nich wirtualny świat gier czy mediów społecz- 
nościowych jest równie ważny jak świat rzeczywisty, a nawet coraz częściej internauci ograniczają dla niego kontakty w świecie fizycznym, co może prowadzić później do różnorodnych problemów w sferze integracji i funkcjonowania w społeczeństwie. Według danych z 2018 roku aktywnymi użytkownikami najpopularniejszego serwisu społecznościowego, jakim jest Facebook, były ponad 2 mld ludzi na świecie, przy czym zanotowano 30-procentowy wzrost korzystających z Messengera, komunikatora internetowego oferowanego przez ten serwis społecznościowy. Jeśli chodzi o funkcjonowanie społeczeństwa brazylijskiego w serwisach społecznościowych, to znalazło się ono na drugim miejscu w rankingu czasu spędzanego na Facebooku, ze średnią wynoszącą prawie 4 godziny dziennie. Chociaż większość użytkowników mieści się w przedziale wiekowym 18-34 lata, to w 2017 roku zanotowano wzrost o 20\% użytkowników w wieku 65 lat i więcej, co świadczy o tym, że korzystanie z mediów społecznościowych już nie jest domeną tylko młodych. Należy dodać, że w Ameryce Południowej sieć internetowa pokrywa ok. 68\% powierzchni kontynentu [Digital in 2018].

Drugą stroną tego problemu jest natomiast wykluczenie cyfrowe, które przez brak dostępu do sieci pozbawia obywateli możliwości korzystania z dóbr i usług, jakie oferuje cyberprzestrzeń. W 2015 roku prezydent Brazylii Dilma Rousseff, odwiedzając siedzibę Google w Kalifornii z okazji dziesięciolecia jego działalności w Brazylii, poruszyła ten istotny temat, szczególnie w odniesieniu do regionu Amazonii, gdzie bardzo słabo jest rozwinięta sieć internetowa. Według danych Google, chociaż Brazylia znajduje się na piątym miejscu na świecie pod względem liczby internautów, to jednocześnie zajmuje ósme miejsce w rankingu wykluczenia cyfrowego [Roussef 2015]. W świecie coraz bardziej zdominowanym i uzależnionym od technologii cyfrowych takie wykluczenie już nie tylko nie pozwala na korzystanie z dobrodziejstw i wygody, jaką oferuje sieć, ale wręcz uniemożliwia pełną partycypację w życiu społecznym czy politycznym.

Nie zapominając o negatywnych aspektach gwałtownego rozwoju technologicznego, nie można zanegować ogromnego skoku cywilizacyjnego, jaki dokonał się dzięki rozwojowi nowoczesnych technologii komunikacyjnych. Dotyczy to szczególnie takich państw, które przez stulecia znajdowały się na peryferiach nowoczesnego, uprzemysłowionego świata. Do państw tych można zaliczyć Brazylię, która dopiero w XXI wieku zaczęła nadrabiać zapóźnienie cywilizacyjne mające podłoże historyczne, związane z przeszłością kolonialną. Aspiracje władz państwowych dążących w swej polityce międzynarodowej do objęcia przez Brazylię roli lidera w regionie Ameryki Łacińskiej spotkały się ze zwiększoną aktywnością obywateli, którzy postanowili wykorzystać dobrą koniunkturę i dostęp do nowoczesnych technologii dla poprawienia swojej sytuacji i walki o bardziej sprawiedliwe i nowoczesne państwo.

O świadomości w kwestii roli trzeciego sektora w obliczu zmieniającej się pozycji Brazylii na arenie międzynarodowej może świadczyć następujący cytat z tekstu deklaracji założeń stowarzyszenia ABONG (Associação Brasileira de Organizações Não Governamentais - Brazylijskie Stowarzyszenie Organizacji 
Pozarządowych): „W ostatniej dekadzie Brazylia znacząco zwiększyła swoje wpływy w geopolityce światowej. Rozwój gospodarczy, polityka wchodzenia w alianse z państwami Ameryki Łacińskiej i Afryki, podejmowanie skoordynowanych działań z innymi wschodzącymi potęgami, a do tego widoczne sukcesy w zakresie innowacyjnych programów socjalnych i partycypacji społecznej, przyciągają uwagę i wzmagają oczekiwania środowiska międzynarodowego wobec brazylijskiego rządu i społeczeństwa obywatelskiego. Organizacje brazylijskiego społeczeństwa obywatelskiego - organizacje pozarządowe, związki zawodowe i ruchy społeczne - były zarówno liderami zmian, jakie mają miejsce, a obecnie są także ich skutkiem. Jeśli chcą zachować aktywną rolę jako podmioty transformacji społecznej i umocnić swoje zaplecze społeczne, polityczne i finansowe, muszą nadążać za tempem zmian i unowocześnić swoje strategie, bacznie wychwytując sygnały o problemach wymagających pilnych rozwiązań, niebezpieczeństwach i możliwościach, jakie przed nimi stoją na drodze do rozwoju społeczeństwa opartego na prawach człowieka, na demokracji i trosce o dobro wspólne" [ABONG 2018].

Z powyższego tekstu można wysnuć wniosek, że choć aktywność społeczeństwa obywatelskiego rozwinęła się na większą skalę dopiero w ostatnich dekadach, to trzeci sektor z pełną świadomością i odpowiedzialnością chce brać udział w walce z problemami systemowymi, jakie trapią Brazylijczyków i stoją na przeszkodzie do pełniejszego i sprawiedliwszego wykorzystania koniunktury gospodarczej.

\section{NOWE TECHNOLOGIE W SŁUŻBIE SPOŁECZEŃSTWA OBYWATELSKIEGO}

Rozwój nowoczesnych technologii komunikacyjnych, a wraz z nimi powstanie cyfrowych zasobów danych dostępnych z dowolnego miejsca świata i w niemalże nieograniczonej przestrzeni wirtualnej, gdzie można prowadzić aktywność publiczną, niewątpliwie ułatwiły działalność organizacjom reprezentującym społeczeństwo obywatelskie. Można wymienić pięć głównych obszarów ich aktywności, które w sposób bezpośredni korzystają z ułatwień, jakie oferuje cyberprzestrzeń [Periotto, Theodoro 2003: 34].

Po pierwsze, jest to komunikacja. Dostęp do sieci pozwala na szybką i tanią formę komunikacji przy wykorzystaniu poczty elektronicznej, komunikatorów, grup dyskusyjnych, czatów itp. Komunikacja w świecie wirtualnym pozwala nie tylko na przesłanie informacji do konkretnych adresatów, ale też umożliwia nawiązanie interakcji, szybkie otrzymanie informacji zwrotnych, zebranie opinii czy udział w procesach decyzyjnych. Poza tym pozwala na stworzenie, szczególnie w przypadku korzystania z serwisów społecznościowych, grupy tzw. followersów, którzy na bieżąco otrzymują informacje o aktywności danego podmiotu, mogą wyrazić w prosty sposób swoją opinię na ten temat, chociażby przez danie „lajka”, czy rozszerzyć grono odbiorców dzięki udostępnieniu danej informacji swoim znajomym w serwisach społecznościowych, z których korzystają na co dzień. 
Po drugie, informacja. Dostęp do sieci jest równoznaczny z dostępem do olbrzymich zasobów informacji udostępnianych na portalach internetowych, które pełnią taką rolę, jaką przed erą dygitalizacji pełniły tradycyjne środki masowego przekazu (prasa, radio, telewizja), przy czym nie są ograniczone zasięgiem lokalnym czy krajowym. Ponadto cyberprzestrzeń może być traktowana również jak wirtualna biblioteka, w której mamy dostęp do olbrzymiej bazy danych, raportów, dokumentów, obrazów, treści aktów prawnych, ich bieżącej aktualizacji. Dotarcie do potrzebnych danych za pomocą jednego kliknięcia jest olbrzymią oszczędnością czasu i środków ${ }^{2}$. W sieci pojawia się coraz więcej stron poświęconych nie tylko praktycznym informacjom przydatnym w bieżącej aktywności trzeciego sektora, ale także służącym rozwijaniu wiedzy naukowej na temat jego funkcjonowania. Przykładem może być ISTR - International Society for Third-Sector Research (Międzynarodowe Towarzystwo Badań nad Trzecim Sektorem). Jego misją jest zbudowanie globalnej społeczności badaczy i innych osób zainteresowanych propagowaniem wiedzy i wspieraniem działalności trzeciego sektora. Dzięki swojej stronie ISTR udostępnia publikacje, raporty, informacje o konferencjach, sylwetki badaczy, a także biuletyny poświęcone działalności regionalnych oddziałów. Taki regionalny oddział Ameryki Łacińskiej i Karaibów istnieje w Brazylii, a ponadto w zarządzie ISTR zasiada przedstawicielka badaczy brazylijskich, Paula Chies Schommer, ze Stanowego Uniwersytetu Santa Catalina [ISTR 2018]. Innym bardzo przydatnym źródłem informacji na temat organizacji działających w trzecim sektorze w Brazylii jest strona prowadzona przez ABONG, która funkcjonuje jako platforma działania, wsparcia, wymiany informacji i edukacji dla podmiotów społeczeństwa obywatelskiego. Stowarzyszenie to powstało w 1991 roku i skupia szerokie spektrum organizacji reprezentujących trzeci sektor. Cele, jakie przyświecają jego działalności, to m.in.: budowa społeczeństwa opartego na zasadach demokracji, zwalczanie wszelkich form dyskryminacji, nawiązywanie współpracy z podmiotami i ruchami lokalnymi i międzynarodowymi dążącymi do przemian strukturalnych, walka z nierównościami społecznymi, obrona praw człowieka, wolności stowarzyszania się i dostępu do środków publicznych, wsparcie instytucjonalne dla członków stowarzyszenia, zwiększanie ich widoczności w sieci [ABONG 2018].

Trzecim ważnym aspektem funkcjonowania podmiotów społeczeństwa obywatelskiego w cyberprzestrzeni jest widoczność w sieci. Umożliwia ona dotarcie z przekazem do szerokich rzesz społeczeństwa - zarówno do osób, które są zainteresowane działalnością danej organizacji, jak i potencjalnych partnerów, sponsorów, beneficjentów, aktywistów. Atrakcyjna, funkcjonalna i właściwie po-

2 Jeśli chodzi o wolny dostęp do informacji, nie sposób pominąć takiej inicjatywy, jak Free Software Foundation (Fundacja Wolnego Oprogramowania), która stworzyła system operacyjny GNU/Linux, umożliwiający korzystanie z sieci przy użyciu darmowego oprogramowania czy też inna bardzo znana inicjatywa, jaką jest Wikipedia, wirtualna encyklopedia tworzona na zasadzie wolontariatu przez internautów i udostępniająca swoje zasoby w sieci. Jest ona obecnie jedną z 10 najczęściej odwiedzanych stron internetowych. Zob.: https://wikimediafoundation.org/wiki/ Strona_g\%C5\%82\%C3\%B3wna [dostęp: 20.04.2018]. 
zycjonowana strona internetowa jest najlepszą wizytówką organizacji w cyberprzestrzeni. A obecność w niej stała się w dzisiejszym świecie niemal koniecznością. Powszechnie uważa się, że młodzi ludzie, którzy rzeczywistość wirtualną traktują jak swoje naturalne środowisko, jeśli nie mogą znaleźć czegoś w sieci, zakładają, że to nie istnieje. Biorąc pod uwagę ogromną liczbę konkurencyjnych organizacji zabiegających o wsparcie w sieci, wiele podmiotów decyduje się na korzystanie z profesjonalnych usług PR lub przynajmniej poradników, które służą do lepszego wykorzystania możliwości, jakie oferują media społecznościowe. Za przykład może posłużyć strona FundsforNGOs, która zamieszcza webinaria, wideo poradnikowe czy artykuły mające na celu profesjonalizację działań organizacji pozarządowych, np. Using Social Media to Enhance Your NGO Visibility [FundsforNGOs 2018].

Kolejną, czwartą kwestią wartą przywołania jest nawiązywanie współpracy w sieci. Media społecznościowe pozwalają na łatwe nawiązanie kontaktu i podjęcie współpracy z dużą liczbą osób skupionych np. wokół konkretnego problemu czy zadania do wykonania. Dzięki temu, że internet pozwala na zniesienie barier geograficznych, daną kwestią może się zainteresować i zaangażować we współpracę dużo większa grupa niż tylko społeczność lokalna. Analizując ten aspekt, można zauważyć, że współpraca w obszarze społeczeństwa obywatelskiego rozwija się dwutorowo: $z$ jednej strony zauważalna jest unifikacja celów (np. walka o ochronę środowiska naturalnego w wymiarze globalnym), a $\mathrm{z}$ drugiej strony dywersyfikacja dzięki dojściu do głosu małych grup zainteresowanych rozwiązaniem problemów lokalnych, które wcześniej nie miały szans na przebicie się do świadomości ogółu.

Ostatnim aspektem, o którym należy wspomnieć, jest zarządzanie. Nowe formy komunikacji, interakcji i rozpowszechniania informacji ułatwiają rozwijanie działalności na szerszą skalę i dają narzędzia do bardziej efektywnego zarządzania realizowanymi projektami. Chodzi tu zarówno o oszczędność środków, jak i sprawniejszy przebieg procesów decyzyjnych, a także wykorzystanie narzędzi nowoczesnego marketingu sieciowego.

Rozszerzając analizę powyżej wymienionych aspektów cyberprzestrzeni, które ułatwiają, a tym samym przyczyniają się do rozwoju działalności trzeciego sektora, należy wspomnieć o takich zjawiskach, jak crowdsourcing czy crowdfunding. Pierwsze z nich polega na zlecaniu wykonania jakiejś pracy, pozyskaniu informacji lub opinii od dużej grupy ludzi, którzy dostarczają je przez strony internetowe, media społecznościowe lub inne aplikacje. Czasem jest to wykonywane za drobną opłatą (na zasadzie outsourcingu), a czasem na zasadzie wolontariatu. Korzystają z tego zarówno firmy komercyjne, jak i organizacje pożytku publicznego [Investopedia 2018].

Przykładem crowdsourcingu może być jedna $\mathrm{z}$ akcji prowadzonych przez pozarządową organizację Observatório da Imprensa (Obserwatorium Prasy), która zajmuje się w Brazylii monitorowaniem rynku prasowego. W 2017 roku opublikowała Atlas Wiadomości - Panoramę dziennikarstwa lokalnego i regionalnego $w$ Brazylii. Jest to raport ukazujący rynek prasy papierowej i elektronicznej, który 
uwidacznia regiony pozbawione lokalnych mediów, przez co obywatele mają w pewnym zakresie ograniczone możliwości korzystania ze swoich praw, chociażby w przypadku kampanii wyborczych, kiedy nie mają szansy poznać lokalnych kandydatów czy też podyskutować o lokalnych bolączkach. Aby zebrać aktualne dane, oprócz informacji otrzymanych od organów państwowych i Krajowego Stowarzyszenia Dziennikarzy, Obserwatorium Prasy skorzystało ze współpracy z wolontariuszami na zasadzie crowdsourcingu, dzięki czemu uzyskało informacje o 287 lokalnych nośnikach wiadomości [Pimenta 2018].

Drugie wspomniane wcześniej zjawisko, czyli crowdfunding, jest natomiast sposobem na zbieranie środków finansowych, również od dużej liczby osób, dzięki czemu nawet bardzo skromne datki mogą złożyć się na pokaźną sumę. W sektorze prywatnym metoda ta jest najczęściej wykorzystywana przez firmy typu start-up, które liczą na bezinteresowne wsparcie od osób, które uda im się przekonać do swojego pomysłu na biznes albo też są gotowe oddać w zamian za wsparcie materialne część udziałów w mającym powstać przedsięwzięciu. Organizacje pozarządowe, szczególnie przeprowadzające zbiórki charytatywne, często korzystają z modelu crowdfundingu.

Opisane powyżej zjawiska crowdsourcingu i crowdfundingu są kolejnym przykładem na to, jak funkcjonowanie w cyberprzestrzeni i rozwój mediów społecznościowych służą społeczeństwu obywatelskiemu. Ani crowdsourcing ani crowdfunding nie miałyby racji bytu, gdyby nie możliwości, jakie daje nowoczesna komunikacja odbywająca się w świecie wirtualnym.

\section{BRAZYLIJSKIE SPOŁECZEŃSTWO OBYWATELSKIE W SIECI}

Wydaje się, że w dzisiejszym świecie prawie każdy obywatel, nawet nie będąc szczególnie biegłym w wiedzy o społeczeństwie, potrafi intuicyjnie opisać to, co rozumie przez termin „społeczeństwo obywatelskie”, gdyż na każdym kroku spotyka się z tym pojęciem, tyle że nie w wymiarze teoretycznym, który wymagałby pogłębionej wiedzy, analizy historycznej, socjologicznej czy semantycznej, a w wymiarze praktycznym, kiedy albo obserwuje działania podmiotów reprezentujących społeczeństwo obywatelskie, albo też sam w nich aktywnie uczestniczy. Nie wdając się więc w rozważania na temat historycznej ewolucji tego pojęcia i jego odcieni znaczeniowych, można posłużyć się ogólną definicją, odwołującą się do celowości społeczeństwa obywatelskiego, według której „istotą społeczeństwa obywatelskiego jest postawa obywatelska członków wspólnoty politycznej. Obywatele podejmując samodzielnie wspólne działania dążą do dobra wspólnego danej społeczności oraz podejmują decyzje w sprawach dla niej istotnych. Samodzielność i samoświadomość są siłą napędową tych obywateli, którzy podejmując się określonych działań mają zapewnić optymalną realizację interesów wszystkich obywateli. Jednostki wykazujące postawę obywatelską są gotowe do przyjęcia odpowiedzialności za daną społeczność, a także do udzielania wsparcia pozostałym 
członkom i poświęcenia w imię dobra wspólnego" [Krasnowolski 2014: 7]. Oprócz takiej podstawowej charakterystyki społeczeństwa obywatelskiego, która odnosi się do wszystkich państw, gdzie ono funkcjonuje, analiza konkretnego przypadku - dla celów niniejszego artykułu jest to casus Brazylii - powinna też uwzględniać pewne uwarunkowania historyczne, polityczne i społeczne, gdyż zmienne te niewątpliwie mają wpływ na kształtowanie się zarówno postaw obywatelskich, jak i mechanizmów, które umożliwiają aktywność społeczną.

W przypadku Brazylii jednym z istotnych czynników, które wpłynęły na rozwój społeczeństwa obywatelskiego, była polityka społeczna, a właściwie antyspołeczna reżimu autorytarnego, która doprowadziła do najszybszego w historii procesu urbanizacji. W jego wyniku w miastach pojawiły się masy biedoty, które osiedlały się w favelach, dzielnicach nędzy, pozbawionych dostępu do jakichkolwiek świadczeń społecznych w zakresie opieki zdrowotnej, edukacji czy infrastruktury miejskiej. I to właśnie walka o zapewnienie sobie podstawowych usług publicznych leżała u źródeł organizowania się społeczeństwa obywatelskiego [Cohen, Rogers 1995: 43].

Kolejnym czynnikiem, który wpłynął na formowanie się ruchów obywatelskich, był fakt, że reżim autorytarny miał wizję rozwoju polityk publicznych jako procesu o charakterze czysto technokratycznym i chciał przeprowadzić modernizację ekonomiczną przez zaangażowanie w nią klasy średniej na zasadzie top-down. W wyniku tego jej przedstawiciele - ekonomiści, lekarze, prawnicy, profesorowie - znaleźli się w awangardzie brazylijskiego społeczeństwa obywatelskiego [Avritzer 2012].

Istotną okolicznością dla rozwoju działań prospołecznych w Brazylii jest fakt, że z jednej strony zalicza się ona do największych państw i gospodarek świata, a z drugiej zajmuje czołowe pozycje w niechlubnych rankingach korupcji, bezrobocia czy trudności z dostępem do edukacji, przez co istnieje olbrzymia przestrzeń do działań społeczeństwa obywatelskiego i ogromne na nie zapotrzebowanie. Jednocześnie społeczeństwo brazylijskie jest relatywnie młode i bardzo aktywne w cyberprzestrzeni. Trudno jest zebrać dokładne dane dotyczące wszystkich inicjatyw podejmowanych przez obywateli. Wynika to zarówno z powodu różnorodności i liczby podmiotów ${ }^{3}$, jak i spektrum ich aktywności, obejmującego

3 Według niektórych źródeł, w zależności od przyjętej definicji podmiotu społeczeństwa obywatelskiego szacuje się, że w Brazylii działa ok. 700-800 tys. takich podmiotów. Zob.: Mapa das Organizações da Sociedade Civil, https://mapaosc.ipea.gov.br/index.html [dostęp: 19.04.2018]. Badacze trzeciego sektora wskazują na kilka aspektów odnośnie do kategoryzacji trzeciego sektora, które nie pozwalają precyzyjnie wyodrębnić podmiotów, które mogą być do niego zaliczone: (a) funkcjonalny - niektórzy badacze uważają, że należy wyłączyć podmioty, które działają jedynie dla wąskich interesów korporacyjnych, (b) prawny - w uproszczeniu przyjmuje się, że organizacje społeczeństwa obywatelskiego mają formę stowarzyszeń lub fundacji, ale takie podejście wyklucza całą rzeszę podmiotów niesformalizowanych, (c) ekonomiczno-finansowy - jest tak duża różnorodność źródeł finansowania i zdobywania środków, że trudno pokusić się o kategoryzację podmiotów, (d) strukturalny/operacyjny - pomimo wypracowania pewnych standardowych założeń zgodnie z Międzynarodową Klasyfikacją Organizacji Pozarządowych (ICNPO - International Classification 
w zasadzie wszystkie aspekty życia społecznego, w których niedomaga państwo: politykę, działalność gospodarczą, edukację, zdrowie, ochronę środowiska, kulturę. Na potrzeby niniejszego artykułu - zarówno jako jeden z przykładów, jak i źródło informacji dotyczących działalności trzeciego sektora w Brazylii - wybrano wspomniany wcześniej portal prowadzony przez Brazylijskie Stowarzyszenie Organizacji Pozarządowych ABONG. Innym obszernym źródłem wiedzy na temat społeczeństwa obywatelskiego funkcjonującego w sieci jest platforma multimedialna Observatório do Terceiro Setor (Obserwatorium Trzeciego Sektora) ${ }^{4}$.

ABONG skupia ponad 250 podmiotów, a zarazem jest członkiem różnorodnych sieci o zasięgu nie tylko krajowym, ale też regionalnym i międzynarodowym funkcjonujących w cyberprzestrzeni, takich jak np. Platforma na Rzecz Reformy Systemu Politycznego, Narodowa Kampania na Rzecz Prawa do Edukacji, Ruch na Rzecz Praw Człowieka, Forum Stowarzyszeń Narodowych i Sieci Organizacji Pozarządowych w Ameryce Łacińskiej i Karaibach, Latynoamerykańskie Stowarzyszenie Organizacji Prorozwojowych itp. Biorąc pod uwagę fakt, że każdy z podmiotów obecnych na platformie $\mathrm{ABONG}$ też współpracuje z pokrewnymi sobie organizacjami, a każda z sieci składa się z kolejnych, licznych podmiotów, można sobie uzmysłowić, jak dużą wartość dla rozwoju ich działalności stanowi możliwość funkcjonowania w cyberprzestrzeni, pozwalająca na nieograniczony rozwój struktury sieciowej i jej globalny zasięg.

Obserwatorium Trzeciego Sektora jest to organizacja zajmująca się zbieraniem i wytwarzaniem treści multimedialnych związanych z tematyką społeczną. Skupia platformy telewizyjne, radiowe i cyfrowe w celu propagowania wiedzy o działaniach trzeciego sektora i dobrych praktyk w tym zakresie. Dba również o obecność tematyki związanej ze społeczeństwem obywatelskim w mediach społecznościowych: na Facebooku, Instagramie, YouTube, LinkedIn. Produkcja medialna i zasoby cyfrowe Obserwatorium są odwiedzane przez 400 tys. użytkowników serwisów społecznościowych i ok. 1,2 mln użytkowników wszystkich kanałów dostępu do cyberprzestrzeni tygodniowo [Observatório 2018]. Dwie najnowsze inicjatywy podjęte przez Obserwatorium w 2018 roku to Capacitar para Transformar (Szkolić by Usprawniać) i Grupo de Excelência (Grupa Doskonalenia). Pierwsza z nich skupia się na organizowaniu seminariów, kursów, wykładów i warsztatów na tematy związane m.in. z pozyskiwaniem i zarządzaniem zasobami czy kierowaniem projektami. Ciekawy i dość nowatorski dział tematyczny dotyczy tak zwanego sektora „dwa i pół”, skupiającego podmioty, które inwestują w działania będące w obszarze zainteresowania trzeciego sektora,

of Nonprofit Organizations) - służą one raczej do celów sprawozdawczych i statystycznych niż odzwierciedlają różnorodność podmiotów funkcjonujących w rzeczywistości [Guerra Silva 2010].

4 Ze względu na strukturę sieciową środowiska, w jakim działają organizacje trzeciego sektora, można założyć z dużą dozą prawdopodobieństwa, że dostęp do wymieniowych portali pozwala dotrzeć do większości podmiotów, które działają w tym obszarze, gdyż w ich interesie jest widoczna obecność, aktywny udział w projektach i korzystanie z zasobów struktur sieciowych w cyberprzestrzeni. 
ale podchodzą do nich jak do przedsięwzięć biznesowych, łącząc zaspokajanie potrzeb społecznych z osiąganiem zysku z tytułu tej działalności. Druga wymieniona inicjatywa skupia profesjonalistów i ekspertów z różnych dziedzin (komunikacji, edukacji, prawa, projektów socjalnych) i ma na celu wypracowanie kreatywnych, skutecznych i innowacyjnych sposobów wykorzystywania danych zbieranych przez Obserwatorium w celu wspierania społeczeństwa obywatelskiego, zgodnie z jego misją przewodnią. Trzeba podkreślić, że Obserwatorium, choć zajmuje się głównie propagowaniem wiedzy dotyczącej społeczeństwa obywatelskiego, nie pomija w swojej działalności nawet drobnych, ale przynoszących wymierne korzyści okazji do wspierania rzeczowo organizacji trzeciego sektora. Przykładem tego może być współpraca z firmą zajmującą się zbiórką śmieci elektronicznych i pomoc $w$ ich recyklingu, dostarczając w ten sposób używane i lekko przestarzałe urządzenia, np. komputery czy drukarki, dla organizacji, które nie mogą sobie pozwolić na zakup nowego sprzętu. Z kolei często organizacje pozarządowe, których działalność skupia się na jakimś konkretnym wycinku życia społecznego, wykorzystują swoje strony internetowe i sieć kontaktów nie tylko do bieżącej pracy w określonym obszarze działania, ale też dzielą się swoją wiedzą, doświadczeniem, a nawet funduszami, aby skłonić obywateli do podjęcia jakiejkolwiek inicjatywy dla dobra ogółu. Przykładem tego może być organizacja FASE, która wyodrębniła z funduszy przeznaczonych na swoją działalność odrębny budżet pod nazwą Roda da Solidariedade (Koło Solidarności). Jego celem jest przyznawanie niewysokich kwot (do 7 tys. reali) podmiotom, które chcą realizować niewielkie projekty o charakterze prospołecznym i mają trudności ze zdobyciem na nie funduszy [FASE 2018b].

Jedną z ciekawszych i wartych przeanalizowania inicjatyw podjętych przez organizacje z trzeciego sektora $\mathrm{w}$ Brazylii jest projekt Novos Paradigmas de Desenvolvimento (Nowe Paradygmaty Rozwoju). Jego celem jest stworzenie nowych modeli rozwoju społecznego. Sprzeciwiając się logice gospodarki opartej na paradygmacie neoliberalnym, polegającym na masowej produkcji, ekstensywnej eksploatacji zasobów naturalnych i rozpasanej konsumpcji, stwarza pole do dialogu i prezentacji alternatywnych kierunków rozwoju nowoczesnej ekonomii, bardziej przyjaznej dla człowieka i środowiska naturalnego. W tym celu stworzono Bank Praktyk Alternatywnych (Banco de Práticas Alternativas). Jest to platforma internetowa, dzięki której przedstawiciele społeczeństwa obywatelskiego mogą zaproponować swoje inicjatywy lub przyłączyć się i czerpać inspiracje z praktyk zaprezentowanych przez innych członków tej społeczności [Banco de Práticas... 2018a]. Zasoby Banku są pogrupowane tematycznie na projekty w następujących obszarach: energia, sztuka, doświadczenie transformacji, miasto, woda, zdrowie, ludy rdzenne, lasy, komunikacja, rolnictwo, transport, praktyki demokratyczne, mieszkanie. Przyjrzyjmy się kilku wybranym inicjatywom Banku Praktyk Alternatywnych.

W obszarze „ludy rdzenne” wyróżnia się Operação Amazônia Nativa OPAN - Operacja Amazonia Autochtoniczna. Jest jedną z pierwszych organizacji poza- 
rządowych, założonych przez przedstawicieli interesów rdzennej ludności Brazylii. Początki jej działalności sięgają 1969 roku. Jej główne cele to: ochrona ziem ludności rdzennej przed wchłonięciem przez rolnictwo wielkoobszarowe, wsparcie dla rozwoju bioróżnorodności na terenach zamieszkałych przez tę ludność, dążenie do samowystarczalności żywnościowej i zrównoważonego rozwoju. Organizacja wspiera też głos ludności rdzennej w sprawach politycznych jej dotyczących [OPAN 2018].

W obszarze „energia” Bank Praktyk Alternatywnych skupia wiele inicjatyw, szczególnie tych dotyczących mikroelektrowni funkcjonujących na bazie energii słonecznej czy wiatrowej. W Brazylii jest jeszcze wiele miejsc, szczególnie w rejonie Amazonii, gdzie infrastruktura energetyczna jest słabo rozwinięta. Jednak korzystanie z najłatwiej dostępnego źródła energii, czyli hydroelektrowni wiąże się z budowaniem tam i szkodliwą dla środowiska naturalnego ingerencją człowieka. Stąd popularność generatorów energii słonecznej. Jednak do jej produkcji konieczne są urządzenia i wiedza technologiczna. Przykładem tego, jak rozwiązać ten problem, może być inicjatywa współpracy pomiędzy trzecim sektorem a firmą komercyjną BrasilSolar, zajmującą się instalacją baterii słonecznych. W ramach projektu Minha Casa Minha Vida (Mój Dom Moje Życie) zainstalowała ona urządzenia do produkcji energii odnawialnej dla 3 tysięcy rodzin. Mogą one korzystać z taniej i czystej energii, a nawet sprzedawać jej nadwyżki i zarabiać w ten sposób [Banco de Práticas... 2018b].

W obszarze „doświadczenie transformacji” jednym z przykładów jest program Jovens gerando renda na agricultura familiar (Dochodowe gospodarstwa indywidualne dla młodych rolników). Jego celem jest wsparcie dla młodych ludzi z obszarów wiejskich, aby mogli nauczyć się tego, jak osiągać wystarczające dochody ze swoich rodzinnych gospodarstw i rozwijać zrównoważone, ekologiczne rolnictwo. Kolejnym celem programu jest również powstrzymanie exodusu młodych ludzi z obszarów wiejskich i zapobieganie wyludnianiu się prowincji. W pierwszym etapie programu, przeprowadzonym w latach 2011-2012, wzięło udział 100 młodych rolników w wieku od 18 do 29 lat z 23 gmin. Drugi etap programu objął 130 rolników w 28 gminach. Polegał na udzieleniu im wsparcia w zorganizowaniu, zarządzaniu i komercjalizacji produkcji rolnej, a także przeprowadzeniu akcji edukacyjnej na temat upraw ekologicznych. Ponadto miał na celu zachęcić ich do aktywnej partycypacji w takich inicjatywach obywatelskich, jak stowarzyszenia, związki zawodowe, spółdzielnie [FASE 2018a].

Inicjatorem opisanego powyżej programu była Federacja Organizacji Pomocy Społecznej i Edukacji FASE (Federação de Órgãos para Assistência Social e Educacional). Jest to organizacja pozarządowa powstała w 1961 roku i działająca obecnie w sześciu stanach Brazylii. Interesująca jest jej droga rozwoju, która pokazuje, jak współczesna historia i polityka Brazylii wpływała na kształtowanie się aktywności obywatelskiej, co z kolei wywołało sprzężenie zwrotne, dzięki któremu społeczeństwo obywatelskie zaczęło mieć większy udział w kształtowaniu swojego otoczenia i polityk publicznych. 
W początkowej fazie swojej działalności, w pierwszej połowie lat 60 . XX wieku FASE zajęła się pracą u podstaw w celu propagowania działalności społecznej i spółdzielczej. Jednak zamach stanu w 1964 roku zmusił ją do zredefiniowania swoich celów. Głównym zadaniem stał się opór przeciw dyktaturze wojskowej i wspieranie związków zawodowych. W latach 70. organizacja zajmowała się głównie problematyką ubóstwa i pracy nieletnich. Z kolei w latach 80., kiedy dyktatura chyliła się ku upadkowi, przyszedł czas na większe zaangażowanie organizacji w politykę przez udział w procesach, które doprowadziły do amnestii więźniów politycznych, przyjęcia nowej konstytucji i wolnych wyborów bezpośrednich. W latach 90. FASE zajęła się rozwijaniem edukacji obywatelskiej i walką o rozwój narzędzi, które pozwoliłyby na większą kontrolę władzy i partycypację społeczną. Wejście w XXI wiek i możliwość korzystania z nowych technologii dostępnych w cyberprzestrzeni pozwoliło organizacji rozszerzyć obszar swoich działań ze skali lokalnej na ogólnokrajową, a nawet międzynarodową [FASE 2018].

Kolejną wartą przytoczenia inicjatywą obywatelską propagowaną przez Bank Praktyk Alternatywnych jest akcja Democratização do acesso à água no Semiárido (Demokratyzacja dostępu do wody w Semiárido) [Banco de Práticas... 2018c]. Dla części społeczeństwa brazylijskiego, żyjącego w tzw. regionie Semiárido, bardzo palącym problemem jest niedostatek wody, wynikający z warunków klimatycznych i utrudniony dostęp do jej zasobów. Polityka państwa w tym zakresie nie spełnia swojej roli nie tyle ze względu na brak inicjatyw, co na niewłaściwe dysponowanie środkami przeznaczonymi na pomoc. Z powodu korupcji polityków i urzędników państwowych i działania na zasadzie klientelizmu fundusze nie są przeznaczane dla najbardziej potrzebujących. W przestrzeni publicznej powstało nawet pojęcie a indústria da seca, czyli ,przemysł suszy”. Polega on na defraudowaniu środków przeznaczonych przez państwo na walkę z suszą zamiast do poszkodowanych rolników, trafiają one do posiadających ogromne zasoby latyfundystów, a ponadto lokalne elity, które są beneficjentami tych środków, nie tylko nie robią nic, by zwalczać przyczyny i skutki suszy, ale wręcz starają się zachować status quo, tak aby móc nadal żerować na pomocy publicznej. Próbę zmierzenia się z tym problemem w obliczu niewydolności państwa podjęła organizacja pozarządowa Articulação Semiárido Brasileiro - ASA (Związek Brazylijski Semiárido). Tak jak w przypadku wspomnianej wcześniej organizacji FASE na historię działalności tej organizacji miała również wpływ polityka. ASA powstała na początku lat 90., kiedy to po okresie dyktatury wojskowej obywatele odczuwali potrzebę zajęcia się sprawami społecznymi. ASA powstała z niezgody na politykę społeczną i ekonomiczną prowadzoną przez państwo w regionie Semiárido. Jest to organizacja sieciowa, która skupia ponad 3 tysiące różnorodnych podmiotów społeczeństwa obywatelskiego: związków zawodowych, spółdzielni rolniczych, stowarzyszeń, organizacji pozarządowych, organizacji pożytku publicznego itp. [ASA 2018].

Początkiem wspomnianej wcześniej inicjatywy był zainaugurowany w 2000 roku program poszerzenia dostępu do wody pitnej Um Milhão de Cisternas (Mi- 
lion Cystern). Dzięki niemu zbudowano 650 tysięcy przydomowych cystern do zbierania deszczówki na cele gospodarstw domowych. Ponieważ projekt zakończył się sukcesem, postanowiono rozszerzyć jego zakres i w 2003 roku zaczął się jego następny etap Uma Terra e Duas Águas (Jedna Ziemia i Dwie Wody). Jego celem było zbudowanie kolejnych cystern, tym razem dużo większych, służących do gromadzenia wody na cele produkcji rolnej, tak aby nie zabrakło jej w okresach szczególnej suszy. Dzięki tej akcji zbudowano 80 tysięcy cystern. Program otrzymał wsparcie władz federalnych, dzięki czemu mógł być przeprowadzony na większą skalę. Kolejnym etapem działania był projekt Cisternas nas Escolas (Cysterny w Szkołach), którego celem było zapewnienie wody pitnej dla dzieci szkolnych, szczególnie w wioskach tubylczych. W 2015 roku program został rozszerzony o projekt Sementes do Semiárido (Nasiona Semiárido). Jego założeniem jest powrót do rolnictwa opartego na endogennych roślinach uprawianych tradycyjnie w regionie w celu zachowania jego bioróżnorodności. Analizując opisany powyżej przypadek, warto zwrócić uwagę, że początkowa inicjatywa wyszła od przedstawicieli społeczeństwa obywatelskiego, pragnących pomóc sobie samym w przezwyciężeniu problemu, którego rozwiązanie niewątpliwie powinno leżeć w gestii państwa i dopiero ich aktywność zmobilizowała reprezentantów władzy do działania. Jak wskazują przedstawiciele ASA, jest to nowatorska droga do konstruowania polityk publicznych i szansa na zbudowanie nowych relacji pomiędzy państwem i społeczeństwem obywatelskim, polegających na tym, że państwo udziela wsparcia autonomicznym i kreatywnym inicjatywom powstałym w ramach społeczeństwa obywatelskiego [Banco de Práticas... 2018c].

Wszystkie opisane powyżej inicjatywy, przeprowadzające i wspierające je organizacje, platformy cyfrowe, na których są umieszczone, zasoby danych z nimi związane itp. są dostępne w internecie. Dzięki funkcjonowaniu w cyberprzestrzeni z łatwością mogą dotrzeć do odbiorców. Ponadto na większości przejrzanych stron są odnośniki do kont tych organizacji w różnych mediach społecznościowych. Najczęściej jest to Facebook, Twitter, Instagram, Pinterest, YouTube. Dzięki stronom na Facebooku mamy dostęp do innych powiązanych i polubionych stron. To z kolei jest źródłem łatwego wyszukania i nawiązania kontaktu z podobnymi im organizacjami czy ich sympatykami. Wszystkie te praktyczne i techniczne aspekty funkcjonowania trzeciego sektora opisane powyżej potwierdzają główną tezę niniejszego artykułu, że cyberprzestrzeń jest doskonałym środowiskiem dla aktywności społeczeństwa obywatelskiego.

\section{KONKLUZJE}

Celem niniejszego artykułu było przeanalizowanie, w jaki sposób nowoczesne środki komunikacji w cyberprzestrzeni wpływają na rozwój społeczeństwa obywatelskiego. Jako przykład wybrano Brazylię z tego względu, że z jednej strony jest to państwo, które boryka się z dużymi problemami wynikającymi z dyspro- 
porcji rozwojowych, wykluczenia społecznego i dysfunkcjonalności wielu struktur państwowych, a z drugiej widać bardzo dynamiczny rozwój trzeciego sektora, który stara się działać tam, gdzie zaniedbania ze strony państwa są najbardziej drastyczne, a także podejmuje inicjatywy zmierzające do systemowych zmian społecznych. W artykule przeanalizowano niektóre formy działalności wybranych organizacji trzeciego sektora w Brazylii, aktywnych w cyberprzestrzeni. Na ich przykładzie można zobaczyć, jak dostęp do rzeczywistości wirtualnej zdywersyfikował formy ich aktywności i jak bardzo praca prospołeczna, wymagająca zaangażowania obywateli, zyskała na dostępie do nowych technologii i komunikacji w cyberprzestrzeni. Przyglądając się bliżej aktywności trzeciego sektora w Brazylii, można stwierdzić, że jego przedstawiciele wykazują się dużą determinacją i inwencją w działaniach na rzecz rozwoju społeczeństwa obywatelskiego i umiejętnie posługują się nowoczesnymi technologiami komunikacyjnymi, tworząc znaczącą grupę cyberaktywistów, którzy - wyposażeni w nowoczesne narzędzia technologiczne - coraz bardziej profesjonalnie podchodzą do realizacji swoich zadań. Na podstawie opisanych przykładów można z całym przekonaniem potwierdzić tezę, że cyberprzestrzeń jest przyjaznym środowiskiem dla prowadzenia działalności prospołecznej i pełni bardzo ważną rolę w budowaniu społeczeństwa obywatelskiego i zmniejszaniu wykluczenia społecznego, a nowoczesne technologie dały obywatelom do ręki potężny oręż do walki o swoje sprawy i wpływ na otaczającą ich rzeczywistość społeczną, polityczną, ekonomiczną i kulturalną.

Title: Cyberspace as an Environment for Civil Society Activity in Brazil

Summary: Access to modern information and communication technologies contributed to the development of active citizenship by facilitating significantly the functioning of non-governmental organizations. It refers to all NGOs but it is particularly important in the areas where government institutions are rather inefficient. Such situation can be observed in Brazil, which was chosen as an object of the analysis in this paper. Non-governmental organizations, depending on citizens who unite voluntarily around a particular cause or idea, due to their very nature must base their activity on a network structure and have to use their modest assets as effectively as possible. Moving great part of their activity to the virtual space facilitated the following aspects of their functioning: communication, information, visibility, cooperation, management. Brazil, although it is regarded as a rising regional power, continues to suffer from various social and economic shortcomings. Moreover, it has a relatively young population, the factor which favors the activity with the use of modern communication technologies. The article analyzes the activity of chosen Brazilian NGOs in cyberspace.

Keywords: civil society, cyberspace, third sector, Brazil 


\section{BIBLIOGRAFIA}

1. Articulação Semiárido Brasileiro - ASA (2018), http://www.asabrasil.org.br/sobre-nos/historia [dostęp: 20.04.2018].

2. Associação Brasileira de Organizações Não Governamentais - ABONG (2018), http://www. abong.org.br/quem_somos.php?id=2 [dostęp: 20.04.2018].

3. Avritzer L., Sociedade civil e Estado no Brasil: da autonomia à interdependência politica, "Opinião Publica", vol. 18 nr 2 Campinas Nov. 2012, http://dx.doi.org/10.1590/S010462762012000200006 [dostęp: 20.04.2018].

4. Banco de Práticas Alternativas (2018a), http://praticasalternativas.org.br [dostęp: 19.04.2018].

5. Banco de Práticas Alternativas (2018b), Minha Casa Minha Vida,http://praticasalternativas.org. br/pratica/microgeracao-de-energia-solar-e-eolica/ [dostęp: 20.04.2018].

6. Banco de Práticas Alternativas (2018c), Democratização do acesso à água no Semiárido,http:// praticasalternativas.org.br/pratica/convivencia-com-o-semiarido-democratizacao-do-acesso-a-agua/ [dostęp: 20.04.2018].

7. Cohen J.L., Rogers J. (1995), Associations and Democracy, Verso, London.

8. Digital in 2018 (2018), We Are Social, https://wearesocial.com/blog/2018/01/global-digital-report-2018 [dostęp: 20.04.2018]

9. Federação de Órgãos para Assistência Social e Educacional - FASE (2018), https://fase.org.br/ pt/quem-somos/historico/ [dostęp: 20.04.2018].

10. Federação de Órgãos para Assistência Social e Educacional - FASE (2018a), Joven sgerandorendanaagri cultura familiar, http://faseb3.wixsite.com/faseba-provisorio [dostęp: 20.04.2018]

11. Federação de Órgãos para Assistência Social e Educacional-FASE (2018b), Roda da Solidariedade, https://fase.org.br/pt/fundos/saap/fundos/ [dostęp: 20.04.2018].

12. FundsforNGOs (2018), Using Social Media to Enhance Your NGO Visibility, https://www.fundsforngos.org/featured-articles/using-social-media-enhance-ngo-visibility/ [dostęp: 20.04.2018].

13. Guerra Silva C.E. (2010), TerceiroSetorBrasileiro: EmBusca de um Quadro de Referência, XXXIV Encontro ANPAD, Rio de Janeiro 25-29 de setembro de 2010, http://www.anpad.org. br/admin/pdf/apb468.pdf [dostęp: 20.04.2018].

14. Internet World Stats (2017), Brazil Internet Stats and Telecom Market Report, https://www. internetworldstats.com/stats10.htm [dostęp: 20.04.2018].

15. Investopedia (2018), Crowdsourcing, https://www.investopedia.com/terms/c/crowdsourcing. asp [dostęp: 20.04.2018].

16. International Society for Third-Sector Research - ISTR (2018),http://www.istr.org/?page=LAC [dostęp: 20.04.2018].

17. Krasnowolski A. (2014), Społeczeństwo obywatelskie i jego instytucje, Biuro Analiz i Dokumentacji, Kancelaria Senatu, Warszawa.

18. Mapa das Organizações da Sociedade Civil (2018), https://mapaosc.ipea.gov.br/index.html [dostęp: 19.04.2018].

19. Observatório do Terceiro Setor (2018), http://observatorio3setor.org.br/quem-somos/ [dostęp: 19.04.2018]

20. Operação Amazônia Nativa - OPAN (2018), http://www.amazonianativa.org.br/ [dostęp: 19.04.2018].

21. Periotto Á.J., Theodoro J.M. (2003), Usoestratégico da internet e as mudançasorganizaçionais do terceirosetor, „Colloquium Humanarum”, vol. 1, nr 1, s. 31-38, jul./dez., 2003, Universidade 
do Oeste Paulista, http://revistas.unoeste.br/revistas/ojs/index.php/ch/article/viewFile/181/85 [dostęp: 19.04.2018]. DOI: https://doi.org/10.5747/ch.2003.v01.n1/h01.

22. Pimenta A. (2018), O ponto de partida do mapa do jornalismobrasileiro no século 21 , Observatório da imprensa, 10 de Maio de 2018, Ano 19, nº86, http://observatoriodaimprensa. com.br/atlas-da-noticia/o-ponto-de-partida-do-mapa-do-jornalismo-brasileiro-no-seculo-21/ [dostęp: 19.04.2018].

23. Roussef D. (2015), "Lutemos para acabar com a exclusãodigital”, komunikat prasowy na portalu rządowym Brazylii z dn. 01.07.2015, http://www.brasil.gov.br/governo/2015/07/dilma-201clutemos-para-acabar-com-a-exclusao-digital201d [dostęp: 20.04.2018].

24. Wikimediafoundation.org (2018), https://wikimediafoundation.org/wiki/Strona_g\%C5\% 82\%C3\%B3wna [dostęp: 20.04.2018]. 